\title{
Inovasi guru dalam pembelajaran di era pandemi COVID-19
}

\author{
Yantoro Yantoro ${ }^{\left.1^{*}\right)}$, Ahmad Hariandi ${ }^{1}$, Zakiah Mawahdah $^{1}$, Mohamad Muspawi $^{1}$ \\ ${ }^{1}$ Universitas Jambi, Indonesia
}

\begin{tabular}{l} 
Article Info \\
\hline Article history: \\
Received Jan $09^{\text {th }}, 2021$ \\
Revised Feb $23^{\text {th }}, 2021$ \\
Accepted Mar $07^{\text {th }}, 2021$ \\
\hline
\end{tabular}

\section{Keyword:}

Inovasi guru

Pembelajaran

Pandemi

\begin{abstract}
Penelitian ini bertujuan untuk menganalisis inovasi guru dalam pembelajaran di era pandemi covid-19 . Metode penelitian menggunakan pendekatan kualitatif dengan jenis penelitian studi kasus. Penelitian ini dilaksanakan di Sekolah Dasar Negeri 55/I Sridadi. Data dalam penelitian ini berupa deskripsi tentang inovasi guru dalam pembelajaran di era pandemi covid-19 yang diperoleh melalui metode wawancara dan observasi sebagai data utama serta dokumentasi sebagai data penunjang. Subjek penelitian adalah kepala sekolah dan guru kelas tinggi yang berjumlah 10 orang. Data di kumpulkan dan di analisis secara kualitatif. Hasil penelitian menunjukkan bahwa guru melakukan beberapa inovasi dalam pembelajaran yaitu merancang pembelajaran dengan membuat skenario pembelajaran, menyiapkan bahan ajar dan media yang akan digunakan baik secara online maupun offline. Pembelajaran dilakukan dengan cara blended learning yaitu dengan membuat sintaks model blended learning (seeeking of information, acquisition of information dan synthesizing of knowledge). Guru juga menerapkan home visit dengan belajar bersama orang tua dan membentuk tutorial sebaya siswa dan orang tua.
\end{abstract}

C 2021The Authors. Published by IICET.

This is an open access article under the CC BY-NC-SA license (https://creativecommons.org/licenses/by-nc-sa/4.0

\section{Corresponding Author:}

Yantoro Yantoro, Universitas jambi

Email: yan.unja@gmail.com

\section{Pendahuluan}

Pandemi covid-19 memberi dampak perubahan pada semua sektor bidang kehidupan baik dampak positif maupun negatif yang mengharuskan pemerintah mencari solusi yang tepat untuk mengatasi semua dampak yang ditimbulkan terutama dampak negatif. Bidang pendidikan merupakan salah satu yang paling mendapatkan dampak serius dari adanya pandemi ini. Adapun dampak yang paling dirasakan adalah proses pembelajaran tidak bisa dilaksanakan secara tatap muka hal ini bertujuan untuk memutus mata rantai penyebaran covid-19 (Anugrahana, 2020). Disisi lain proses pembelajaran tetap harus berjalan, siswa harus menerima haknya sebagai warga negara dalam memperoleh pendidikan yang layak dan berkualitas. Upaya untuk menjawab tuntutan tersebut adalah melakukan proses pembekajaran yang sesuai dengan kondisi pandemi saat ini yaitu pembelajaran dilaksanakan secara daring (Nofitasari,2021).

Melalui kementerian pendidikan dan kebudayaan, pada tanggal 24 Maret 2020, Menteri Pendidikan dan Kebudayaan Republik Indonesia mengeluarkan Surat Edaran Nomor 4 Tahun 2020 tentang Pelaksanaan Kebijakan Pendidikan Dalam Masa Darurat Penyebaran Covid-19. Dalam surat edaran mengamanatkan bahwa pembelajaran dilaksanakan secara daring (dalam jaringan) atau dari rumah (jarak jauh) untuk seluruh siswa hingga mahasiswa karena adanya pembatasan sosial sebagai upaya untuk memperkecil angka penyebaran virus corona. 
Menerapkan pembelajaran secara daring, menuntut semua pihak yang terlibat dalam proses pembelajaran harus memiliki kesiapan seperti jaringan internet dengan konektivitas yang memadai serta fasilitas lainnnya yang dapat menunjang agar proses pembelajaran secara daring dapat dilaksanakan dengan baik (Sadikin dan Hamidah, 2020). Pembelajaran dalam jaringan diterapkan dengan menyeseuaikan kesiapan dari sekolah itu sendiri (Dewi, 2020) Namun tidak bisa dipungkiri bahwa tidak semua siswa, guru ataupun pihak sekolah memiliki kemampuan atau kesiapan untuk melakukan pembelajaran secara daring.

Model pembelajaran memilki pengaruh yang besar terhadap prestasi maupun motivasi belajar siswa. Salah satu hasil penelitian menunjukkan bahwa model pembelajaran memilki pengaruh terhadap motivasi dan prestasi belajar siswa adalah penelitian oleh Izuddin Syarif (2012) yang berjudul pengaruh model blended learning terhadap motivasi dan prestasi belajar siswa yang mana hasil penelitiannya menunjukkan adanya perbedaan yang signifikan antara motivasi dan prestasi belajar siswa yang menggunakan model blended learning dan siswa yang menggunakan model face-to-face learning.

Selain itu, faktor terpenting dalam pembelajaran adalah guru (Bhargava dan Pathy, 2011). Guru merupakan profesi atau pekerjaan yang memerlukan keahlian khusus atau profesionalisme guru. Dalam proses pembelajaran, guru di tuntut harus aktif, inovatif dan kreatif agar siswa tidak merasa bosan dengan kegiatan pembelajaran yang dilakukan baik secara daring atayan.unja@gmail.comupun tatap muka. Terlebih lagi pada masa pandemi covid-19 saat ini. Guru harus pandai memodifikasi pembelajaran dengan model yang inovatif dan kreatif. Menurut Syaharuddin (2020), pembelajaran di masa pandemi covid-19 menjadi sangat bervariasi, ada berbagai model pembelajaran yang digunakan saat ini diantaranya, daring method, luring method, tatap muka murni, home visit, blended learning dan lainnya. Salah satu model pembelajaran yang dapat dilakukan pada kondisi saat ini adalah model pembelajaran kombinasi atau yang dikenal dengan istilah blended learning, karena dinilai mampu membentuk dan mengembangkan kemandirian belajar siswa hingga mahasiswa (Yuliati, Saputra: 2020).

Kondisi saat ini banyak di temui guru terutama guru sekolah dasar mengalami kesulitan dan belum siap melakukan proses pembelajaran di era pandemi, terutama pembelajaran secara daring. Sekolah belum siap dengan berbagai fasilitas yang dibutuhkan dalam pelaksaaan pembelajaran daring, disisi lain guru belum terbiasa bahkan belum dibekali bagaimana cara pembelajaran daring yang memanfaatkan beberapa teknologi sebagai salah satu yang dipersyarakan. Kebanyakan guru masih gagap dalam teknlogi terutama teknologi informasi. Kondisi seperti ini jelas akan membawa dampak negatif bagi pelaksanaan proses pembelajaran yang berujung pada kurang tercapainya tujuan pembelajaran yang telah ditetapkan.Untuk itu guru dimasa pandemic covid 19 ini dituntut untuk selalu berinovsi tertama dalam pelaksanaan pembelajaran dimulai dari perencanaan pembelajaran,pelaksanaan proses pembelajaran dan evaluasi pembelajaran .

Pada tanggal 5 Oktober 2020 peneliti melakukan observasi dan wawancara kepada kepala sekolah dan beberapa guru kelas yaitu wali kelas tinggi SD Negeri 55/I Sridadi untuk memperoleh informasi bagaimana proses pembelajaran dilakukan di sekolah ini dan apa inovasi yang dilakukan oleh guru dalam proses pembelajaran. Informasi yang didapatkan bahwa sekolah tersebut melakukan proses pembelajaran secara daring dan tatap muka atau lebih dikenal dengan istilah blended learning serta kunjungan ke rumah siswa. Menurut Istiningsih dan Hasbullah (2015) terdapat tiga tahapan dasar dalam model blended learning yang mengacu pada pembelajaran berbasis ICT, yaitu sebagai berikut :

\section{Seeking of information}

Mencakup pencarian informasi dari berbagai sumber informasi yang tersedia secara online maupun offline dengan berdasarkan pada kebutuhan belajar. Guru atau fasilitator berperan memberi masukan bagi siswa untuk mencari informasi yang efektif dan efisien.

\section{Acquisition of information}

Siswa secara individu ataupun kelompok berupaya untuk menemukan, memahami serta mengkonfigurasikannya dengan ide atau gagasan yang telah ada dalam pikiran siswa sebelumnya. Kemudian siswa menginterpretasikan informasi atau pengetahuan dari berbagai sumber yang tersedia, sampai mereka mampu mengkomunikasikannya kembali dan menginterpretasikan ide dan hasil interpretasinya menggunakan fasilitas online atau offline

\section{Synthesizing of knowledg}

Pada tahap ini siswa mengkonstruksi/merekonstruksi pengetahuan melalui proses asimilasi dan akomodasi bertolak dari hasil analisis, diskusi dan perumusan kesimpulan dari informasi yang diperoleh kembali dan menginterpretasikan ide-ide dan hasil interpretasinya menggunakan fasilitas online atau offline. 


\section{Metode}

Penelitian ini dilaksanakan di kelas tinggi SD Negeri 55/I Sridadi. Pendekatan dalam penelitian ini menggunakan pendekatan kualitatif dengan jenis penelitian studi kasus. Tujuan penelitian ini adalah untuk mendiskripsikan dan menganalisis inovasi yang dilakukan guru dalam pembelajaran di era pandemi covid-19. Adapun subjek penelitian dalam penelitian ini adalah kepala sekolah dan guru kelas tinggi yang berjumlah 9 yang terdiri dari kelas 4 sebanyak 3 orang guru, kelas 5 sebanyak 3 orang guru dan kelas 6 sebanyak 3 orang guru. Teknik pengumpulan data dalam penelitian ini adalah teknik observasi, wawancara dan dokumentasi.. Uji validitas data dalam penelitian ini menggunakan teknik triangulasi. Jenis triangulasi yang digunakan adalah triangulasi teknik dan sumber. Teknik analisis data dilakukan dalam bentuk deskriptif kualitatif. Proses dalam menganalisis data ini menggunakan model kualitatif dari Miles dan Huberman (Sugiyono: 2017)

\section{Hasil dan Pembahasan}

Obsevasi dan wawancara yang dilakukan kepada guru kelas tinggi dan kepala sekolah tentang pelaksanaan pembelajaran di era pandemi covid-19 memberikan jawaban bahwa pembelajaran yang dilaksanakan di sekolah ini (SD Negeri 55/I Sridadi) dilakukan dengan cara blended learning yaitu suatu bentuk pembelajaran yang menggabungkan atau mengombinasikan pembelajaran konvensional tatap muka dan pembelajaran dengan cara online berbasis teknologi informasi (Pembelajaran dilakukan dalam jaringan). Hal ini sesuai dengan hasil wawancara dengan kepala sekolah yang mengatakan bahwa:

"pembelajaran disekolah ini selama adanya pandemi covid-19 mengikuti surat edaran yang dikeluarkan oleh Kementerian Pendidikan dan Kebudayaan No. 4 tahun 2020 tentang pelaksanaan kebijakan pendidikan dalam masa darurat penyebaran covid 19, menggunakan model pembelajaran secara online, pembelajaran dilalukan secara daring yaitu pembelajaran dari rumah, namun karena kondisi belum semuanya guru mempunyai kemampuan melakukan pembelajaran daring maka pembelajaran dilakukan secara tatap muka dengan waktu yang singkat serta mematuhi protokol kesehatan yang ketat dalam arti kata pembelajaran campuran yaitu pembelajaran secara konvesional tatap muka dan pembelajaran secara daring. Pembelajaran secara tatap muka setelah mendapat izin dari wali murid" (Kepala Sekolah)

Pernyataan yang sama juga dikatakan oleh guru kelas tinggi bahwa :

"selama masa pandemi proses pembelajaran yang dilakukan khususnya di kelas tinggi menggunakan model blended learning yaitu menggabungkan proses pembelajaran tatap muka dan dalam jaringan. Hal ini dilakukan mengingat tidak semua pihak mampu melaksanakan pembelajaran secara daring sepenuhnya karena ada beberapa siswa yang tidak memiliki android untuk mengakses pembelajaran. Hal ini akan menghambat proses pembelajaran nantinya" (Wali kelas IV C).

Sedangkan wali kelas VC menyatakan :

"pelaksanaan pembelajaran di SD Negeri 55/I Sridadi berdasarkan kesepakatan dilaksanakan secara blended learning atau kombinasi sesuai dengan hasil kesepatan bersama antara guru dan wali murid serta komite sekolah. Hal ini dikarenakan tidak memungkinkan jika dilakukan pembelajaran secara daring sepenuhnya". (Wali Kelas V C)

Dalam upaya menguatkan dan keberhasilan pelaksanaan pembelajaran daring yang dilakukan oleh guru, pihak sekolah melakukan beberapa usaha antara lain melengkapi sarana dan prasarana yang dibutuhkan guru dan membekali guru dalam pembelajaran dengan memberikan pelatihan kepada guru tentang penggunaan teknologi informasi dalam pembelajaran. Hasil observasi menunjukkan bahwa guru dalam melakukan pembelajaran secara daring pilihan pertama dalam pembelajaran adalah meggunakan WhatsApps (WA) dengan alasan aplikasi ini sudah familiar, mudah digunakan dan anak juga sudah paham atau sering menggunakan aplikasi ini, mudah dijangkau oleh semua orang tua. Sedangkan sebagian guru menggunakan aplikasi zoom meeting dan youtube. Hal ini sesuai dengan hasil wawancara dengan guru kelas $\mathrm{V}$ A tentang media apa yang digunakan guru dalam pembelajaran. Jawaban yang diberikan guru adalah:

"dalam pelaksanaan pembelajaran daring hampir $100 \%$ guru melakukan pembelajaran secara daring dengan meggunakan media WhatsApps (WA) karena media ini sudah familiar dan fitur-fitur dalam WA juga sudah sering digunakan oleh guru. Hanya sekitar 25\% yang menggunakan aplikasi zoom meeting dan youtube"(Wali Kelas V A)

Kemudian responden lainnya juga mengungkapkan bahwa :

"ada banyak media online yang dapat digunakan dalam proses pembelajaran daring ini. Ada WA, Google Classroom, Zoom meeting, Google form, dan masih banyak lainnya. Namun dikarenakan kemampuan guru terutama yang sudah tua ini sangat minim dalam menguasai teknologi maka dari itu tidak semua media online dapat dikuasai. Hanya WA yang 
paling dikuasai oleh guru di sekolah ini. Sebagian lagi juga sudah menguasai zoom meeting. Dan ada beberapa guru yang sudah sangat menguasai berbagai media online. Sehingga guru lainnya dapat belajar dengannya". (Wali kelas VI C)

Dalam pembelajaran secara daring terlihat guru melakukan beberapa inovasi. Dari hasil observasi dan wawancara didapat data guru dalam melakukan proses pembelajaran agar pembelajaran mencapai tujuan pembelajaran melakukan inovasi antara lain hampir semua guru (80\%). Guru menyiapkan materi pembelajaran dengan cara membuat ringkasan materi pelajaran setiap sub tema, membuat bahan ajar yang menarik misal dalam bentuk power point (PPT) dan mengakses video pembelajaran sesuai materi pembelajaran, dan membuat LKPD yang interaktif. Susiyanti dan Nugraheni (2020) mengatakan video pembelajaran merupakan salah satu solusi yang dapat membantu siswa memahami materi karena video dapat diputar berulang-ulang. Semua materi yang diberikan guru tersebut dishare melaui WA Group kelas. Hal ini sesuai dengan pernyataan oleh guru kelas tinggi berikut:

"Inovasi yang dilakukan oleh guru adalah memberikan penjelasan secara detail bagaaimana langkah langkah dalam belajar. Pertama setelah materi dishare di WAG, siswa harus mempelajari materi pelajaran, baik itu ringkasan materi, buku yang akan dibaca siswa, PPT yang telah diberikan serta video pembelajaran untuk dilihat serta LKPD yang harus dikerjakan.

"guru terus diminta untuk berinovasi agar pembelajaran berjalan lancar dan tidak membosankan. Sehingga guru menyampaikan materi ke siswa dan orang tua sehari sebelum pembelajaran untuk dipelajari dan didiskusikan dengan teman sekelas atau dengan orang tua siswa. Dengan harapan orang tua bisa membimbing anaknya dalam belajar maupun mengerjakan latihan. Guru juga mengadakan pertemuan lewat zoom meeting untuk menjelaskan materi pembelajaran agar materi yang disampaikan dapat diterima dengan jelas oleh siswa". (Wali kelas IV B)

Dalam pelaksanaan pembelajaran dengan menggunakan media WAG terlihat guru juga melaukan video call dengan siswa, terutama siswa yang mengalami kesulitan dalam memahami materi pelajaran, guru dan siswa juga menggunakan rekam suara. Salah satu fitur di WA untuk merekam suara yang berguna untuk bertanya atau memberikan ulasan tugas. Tugas yang diberikan kepada siswa juga dikumpulkan lewat WAG, diskusi juga dilakukan melalui WAG. Guru sangat memanfaatkan fitur -fitur yang ada dalam WA untuk membantu proses pembelajaran. Hal ini sesuai dengan pernyataan oleh guru kelas tinggi berikut :

"dikarenakan WA adalah media yang paling dikuasai, maka wa sangat dimanfaatkan dalam proses pembelajaran. Fiturfitur wa harus sangat dimanfaatkan. Seperti video call, wa gruop dan voice note sangat membantu proses pembelajaran secara daring terutama pesan suara atau voice note sangat membantu guru dalam menjelaskan materi karena kadang dalam bentuk ketikan sulit untuk dipahami siswa". (Wali kelas VI A)

Kendala kendala dalam pembelajaran daring berdasarkan hasil observasi dan wawancara sering ditemui antara lain ketersedian jaringan yang belum memadai artinya kondisi jaringan yang tidak stabil, kondisi listrik yang kadang mati yang mempengaruhi jaringan dan ketersediaan daya baterai, serta terbatasnya HP android yang dimiliki oleh orang tua siswa atau siswa juga menjadi kendala. Disisi lain masih juga ditemui ada sebagian kecil guru yang masih belum sepenuhnya mengoperasikan beberapa media untuk pembelajaran daring dan yang paling dominan adalah kemampuan orang tua mendampingi anaknya di rumah dalam pembelajaran juga masih terbatas. Semua kendala ini menjadi faktor yang bisa menghambat keberhasilan pembelajaran daring. Hal ini sesuai dengan hasil wawancara dengan salah satu guru kelas tinggi yang mengatakan bahwa :

"banyak yang bisa mengurangi keberhasilan pembelajaran secara daring antara lain faktor dari kami sendiri artinya faktor dari guru, faktor sarana prasarana antara lain jaringan yang kurang stabil, listrik juga kurang stabil, ketersediaan HP android orang tua siswa dan keterbatasan waktu orang tua dalam mendampingi anaknya juga sangat terbatas, kadang orang tua juga tidak paham akan materi pelajaran, sehingga kesulitan untuk membantu anaknya" (Wali kelas IV B)

Berdasarkan hasil penilaian yang dilakukan oleh guru tentang pembelajaran secara daring, mendapatkan hasil bahwa pelaksanaan pembelajaran daring masih belum optimal dalam mencapai tujuan pembelajaran.Untuk mengatasi permasalahan pelaksanaan pembelajaran daring maka guru melakukan pembelajaran secara luring atau pembelajaran luar jaringan secara tatap muka terbatas.

Dalam pembelajaran secara luring dengan cara tata muka terbatas, guru melakukan pembelajaran dengan cara mematuhi protokol kesehatan yang ketat, jam pelajaran yang singkat dan jumlah siswa yang belajar dibatasi dan juga dilakukan secara bergilir serta mendatangkan orang tua. Dalam pembelajaran secara luring guru menggunakan buku pelajaran, terkadang modul pelajaran membahas materi-materi pelajaran yang kurang dipahami oleh siswa, mengerjakan latihan secara bersama dan menyampaikan materi berikutnya 
yang akan dan harus dipelajari dan dikuasai siswa. Guru juga berdiskusi dengan wali murid yang datang mengantarkan anaknya untuk membahas tentang pelajaran anaknya dan menyampaikan materi pelajaran. Guru juga menyampaikan materi pelajaran kepada orang tua yang diangap sulit oleh orang tua. Disamping penyampaian materi guru memberikan motivasi dan dorongan kepada orang tua agar selalu bersama meluangkan waktu untuk menemani anak dalam belajar disaat pandemi covid-19 ini. Hal ini sesuai dengan hasil wawancara dengan kepala sekolah dan guru kelas $\mathrm{V}$ tentang pembelajaran luring yang mengatakan:

"Dimasa pandemi ini selain pembelajaran daring juga dengan melakukan pembelajaran luring dengan menerapkan protokol kesehatan yang ketat dan medapatkan izin dari orang tua, disamping itu waktu belajar juga singkat dan dilakukan secara begilir. Pembelajaran luring ini membahas materi yang belum dikuasai siswa dan juga bisa bertemu dengan orang tua yang menyerahkan jawaban latihan yang diberikan guru"(Kepala sekolah)

"Pembelajaran secara daring belum memcapai hasil yang maksimal masih banyak kendala kendala yang dihadapi, maka untuk memperkecil masalah pembelajaran daring maka di sekolah ini juga melakukan pembelajaran secara luring atau pembelajaran tatap muka dengan izin wali murid dan komite sekolah, dalam pembelajaran luring harus mentaati protokol kesehatan, jam pelajaran juga dibatasi dan siswa dilakukan secara begiliran"(Wali kelas V C)

Inovasi guru dalam pembelajaran di era pandemi covid-19 di SD Negeri 55/I Sridadi, agar pembelajaran mencapai tujuan pembelajaran yang telah ditetapkan, guru melakukan beberapa terobosan antara lain melakukan pendataan kepada siswa-siswa yang mengalami kendala dalam pembelajaran daring. hal ini sesuai dengan hasil wawancara dengan wali kelas tinggi berikut:

"kendala yang sering ditemui diantaranya tidak semua siswa mempunyai HP android atau keterbatasan HP android yang dimiliki anak atau orang tua, hambatan lain yaitu anak anak yang belum memahami materi pelajaran yang ditandai dengan kemampuan anak dalam menjawab latihan-latihan soal yang berikan oleh guru secara benar masih minim belum sesuai ketuntasan belajar". (Wali kelas V B).

Untuk mengatasi hambatan tersebut sebagian guru melakukan inovasi yaitu melakukan kunjung rumah siswa (home visit) yang mengalami kendala dalam mengikuti pembelajaran dengan membentuk cluster cluster belajar. Kelompok kelompok atau cluster cluster siswa didasarkan pada kesulitan siswa dalam menguasai materi pembelajaran yang sama, dengan harapan guru akan mudah mennyampaikan materi pelajaran.

Dalam melakukan home visit guru bertemu dengan siswa dan orang tua siswa yang anaknya mengalami kesulitan belajar. Dalam home visit guru membahas materi-materi pelajaran yang belum dipahami oleh siswa dan memberikan contoh-contoh soal untuk dikerjakan. Pada akhir kegiatan guru memberikan latihanlatihan soal untuk dikerjakan. Ketika siswa mengerjakan latihan soal, guru menjelaskan materi pelajaran kepada orang tua dengan harapan oran tua bisa mendampingi anaknya belajar dirumah. Kegiatan ini silih berganti disetiap cluster setiap hari dalam waktu yang telah ditentukan oleh guru. Dalam pembelajaran setiap cluster, guru menggunakan cara pembelajaran tutorial sebaya, bagi anak yang sudah memahami materi pelajaran diminta untuk dapat membimbing temannya yang belum paham. Dalam kegiatan home visit guru melakukan protokol kesehatan yang ketat.

Hal ini sesuai dengan hasil wawancara yang dilakukan peneliti kepada guru kelas tinggi yang mengatakan bahwa :

"Untuk mengatasi kendala kendala yang dialami siswa dalam mengikuti pembelajaran khususnya pembelajaran daring dan luring, guru melakukan kegiatan kunjungan ke rumah siswa (home visit) memberikan layanan belajar kepada siswa yang mengalami hambatan belajar dengan membentuk kelompok kelompok belajar (cluster-cluster) berdasarkan kesamaan masalah yang dihadapi oleh siswa. Guru juga memberikan layanan belajar atau diskusi kepada orang tua, memberi motivasi untuk membantu anak dalam belajar di rumah dalam melakukan kunjungan ke rumah siswa dengan menerapkan protokol kesehatan" (Wali kelas V A)

Pernyataan yang sama juga disampaikan oleh guru kelas VI

"mengenai kendala yang ada, sebagian guru melakukan inovasi pembelajaran dengan metode home visit. Dimana guru akan datang ke rumah siswa berdasarkan kelompok-kelompok belajar yang telah ditentukan sebelumnya. Selain itu guru akan meminta bantuan siswa yang sudah paham untuk mengajari temannya" (Wali kelas VI A) 
"proses pembelajaran dilakukan secara daring dan luring yaitu dengan metode blended learning. Dimana pembelajaran daring yang dilakukan memang belum optimal sehingga perlu dikombinasikan dengan pembelajaran tatap muka salah satunya melalui kunjung rumah siswa atau dikenal dengan istilah home visit”. (Wali kelas VI B)

Berdasarkan hasil observasi dan wawancara di dapat jawaban bahwa dalam masa pandemi covid-19 guru di SD Negeri 55/I Sridadi melakukan pembelajaran dengan cara pembelajaran daring dan luring (Blended Learning) dan kunjungan ke rumah siswa membentuk cluster-cluster belajar sesuai dengan masalah yang dihadapi siswa. Dalam melalukan pembelajaran di era pandemi guru melakukan beberapa inovasi antara lain guru merencanakan dan menyiapkan materi, bahan ajar dan media pembelajaran yang interatif sesuai kondisi siswa dengan mengoptimalkan sumber belajar yang tersedia dan sesuai dengan lingkungan belajar siswa. Guru juga memberikan layanan belajar dari rumah ke rumah siswa dan berkolaborasi dengan orang tua untuk memberikan pendampingan belajar di rumah.

Keberhasilan proses pembelajaran sangat ditentukan oleh kemauan guru dalam berinovasi mulai dari inovasi persiapan pembelajaran, pelaksanaan pembelajaran dan evaluasi pembelajaran. Dimasa pandemi covid-19 proses pembelajaran mengalami pergeseran, yang mana selama ini guru melakukan proses pembelajaran secara konvesional atau tatap muka. Dengan kondisi dan situasi penyebaran covid-19 yang semakin meningkat demi menjaga kesehatan para siswa, guru, warga sekolah serta masyarakat, maka proses pembelajaran dilakukan secara jarak jauh dengan menggunakan jaringan internet (daring). Hal ini mengacu pada Surat Edaran Menteri Pedidikan dan Kebudayaan No. 4 Tahun 2020 tentang Pelaksanan Kebijakan Pendidikan Dimasa Darurat Penyebaran Covid-19.

Permasalahan timbul saat proses pembelajaran secara daring antara lain adalah, pola kebiaasan guru dan siswa yang belajar dari cara konvensional menjadi daring. Guru kurang siap dan belum mempunyai kemampuan yang memadai. Kondisi sarana dan prasarana mulai dari jaringan internet yang kurang stabil dan tidak merata, listrik yang kadang padam juga menjadi masalah pembelajaran secara daring. Disamping itu media belajar yang digunakan seperti laptop, Hp android juga belum semua siswa memilikinya. Semua kendala ini akan berimplikasi dalam pembelajaran dan bermuara akhir pada hasil belajar peserta didik yang kurang mencapai tujuan pembelajaran. Untuk mengatasi masalah ini maka guru dituntut untuk berinovasi agar pembelajaran di masa pandemi covid-19 bisa berhasil mencapai tujuan.

Model pembelajaran blended learning atau pembelajaran campuran menjadi pilihan dalam proses pembelajaran di SD Negeri 55/I Sridadi pada masa pandemi covid-19. Nugraha (2020) mengatakan penerapan blended learning di sekolah, diharapkan dapat menjadi alternatif yang handal dalam mewujudkan suasana pembelajaran yang aktif, menyenangkan serta bermakna bagi siswa. Proses pembelajaran dilakukan secara online dan tatap muka. Guru menyiapkan beberapa perencanaan sebagai inovasi pembelajaran dalam penerapan model pembelajaran blended learning agar siswa dapat memperoleh pembelajaran dengan baik dan maksimal serta pembelajaran yang dilakukan menjadi bervariasi. Hal ini sesuai dengan pendapat Aman Maathoha (2017) yang menjelaskan bahwa pembelajaran blended learning merupakan model pembelajaran yang menggabungkan berbagai model, gaya belajar serta media yang berbasis teknologi, pembelajaran pun bisa dilakukan secara face to face, belajar mandiri lewat jaringan. Pembelajaran model ini juga didukung oleh kombinasi efektif dari berbagai segi mulai dari cara penyampaian dan gaya mengajar. Disisi lain ada suatu nuansa yang positif antara guru dan orang tua mendorong siswa untuk belajar.

Menurut Iriansyah (2020), Inovasi dilakukan untuk menjawab permasalahan pendidikan, yang mana dengan inovasi, kreatifitas dan usaha yang terus menerus akan menemukan cara-cara baru dan dapat menjadikan sesuatu menjadi lebih baik. Inovasi guru dalam pembelajaran dimasa pandemi dimulai dari pembuatan RRP berbasis Blended Learning. Rencana pelaksanaan pembelajaran merupakan komponen penting dalam sebuah proses pembelajaran. Oleh sebab itu perlu dipersiapkan dengan baik oleh guru. Salah satu inovasi yang dilakukan guru dalam model pembelajaran blended learning adalah merancang RPP yang sesuai dengan model pembelajaran blended learning. Dalam RPP yang dirancang, guru berinovasi dengan menambahkan tahapan blended learning yang terdiri dari tahapan seeking of information, acquisition of information dan synthesizing of knowledge dalam kegiatan pembelajaran. Meskipun tidak tertulis secara langsung sintaks blended learning, namun kegiatan-kegiatan pembelajaran dalam RPP merupakan bagian dari tahapan atau sintaks dari blended learning. Tahapan ini tidak akan ditemui pada RPP pada umumnya karena perancangan RPP memuat kegiatan belajar mengajar yang disesuaikan dengan tahapan blended learning. Kegiatan yang dilakukan mulai dari mengumpulkan informasi, berdiskusi hingga mengevaluasi.

Adapun contoh kegiatan yang dilakukan pada pembelajaran online tahapan seeking of information, yaitu seperti melalui whatsapp group, guru meminta siswa mengamati gambar dan memahami bahan bacaan yang terdapat pada buku siswa sesuai dengan materi pembelajaran yang sedang dibahas. Kemudian guru meminta 
siswa mencari informasi melalui link mengenai video pembelajaran yang sudah disediakan. Selain itu guru juga meminta siswa untuk mencari informasi lain mengenai materi pembelajaran baik dari buku maupun internet. Kemudian untuk tahapan acquisition of information, siswa dan guru berdiskusi membahas materi pembelajaran yang telah diamati melalui video pembelajaran, mereka saling bertanya jawab melalui zoom meeting atau video call whatsapp. Guru selalu memancing siswa untuk bertanya dan mengeluarkan pendapat. Selanjutnya pada tahapan synthesizing of knowledge, guru dan siswa menyimpulkan pembelajaran bersamasama melalui zoom meeting atau video call whatsapp tersebut.

Sementara pada kegiatan pembelajaran tatap muka, guru akan meminta siswa menandai halamanhalaman pada buku siswa yang belum mereka pahami pada saat belajar dari rumah. Setelah itu guru dan siswa pun berdiskusi membahas satu persatu halaman-halaman tersebut (acquisition of information). Kemudian guru meminta siswa mempresentasikan hasil diskusi atau menjelaskan apa yang telah mereka pelajari di depan kelas (synthesizing knowledge). Pembelajaran dengan menggunakan blended learning akan mampu meningkatkan hasil belajar yang optimal dikarenakan dalam pembelajaran tersebut terjadi pergeseran pembelajaran yang awalnya semua berpusat pada guru kini menjadi berpusat pada siswa (Pujiasih, 2020). Pembelajaran blended learning mampu membangun interaksi yang positif dan kreatif antara seluruh komponen pembelajaran dengan sumber belajar lainnya (Widiara, 2018)

Kemampuan mengajar guru sangat berpengaruh terhadap pencapaian siswa (Panambaian, 2020). Dalam pembelajaran di masa pandemi covid-19 inovasi lainnya yang dilakukan guru adalah menyusun bahan ajar yang kreatif seperti menggunakan video pembelajaran yang menarik. Guru mengedit video sedemikian rupa sehingga menjadi video yang menarik perhatian siswa. Selain itu guru juga menyiapkan power point yang memuat materi pembelajaran yang juga dapat diselipkan video pembelajaran sehingga proses pembelajaran menjadi inovatif. Bahan ajar ini dapat dijadikan media pembelajaran saat menggunakan zoom meeting. Guru akan menggunakan video pembelajaran yang telah diedit saat melakukan pembelajaran dengan zoom meeting, setelah siswa menonton video, guru akan meminta siswa berdiskusi dan berkomentar mengenai video yang telah ditonton. Guru akan meminta saran kepada siswa mengenai apa yang masih kurang dalam video tersebut. Sehingga proses pembelajaran tidak hanya menjadi sumber belajar bagi siswa, namun juga dapat menjadi media diskusi antara siswa dan guru dalam menciptakan pembelajaran yang efektif.

Home visit merupakan salah satu inovasi yang digunakan guru apabila pembelajaran tatap muka di sekolah tidak bisa dilaksanakan secara maksimal atau siswa yang masih terkendala pada pembelajaran online. Guru akan bersedia melakukan home visit atau kunjungan rumah. Menurut Makmun (2021), home visit dapat memenuhi kebutuhan siswa dalam melakukan pembelajaran. Home visit merupakan salah satu alternatif yang dapat dipilih untuk mengoptimalkan pembelajaran luring di masa pandemi (Kurniawan, 2021).

Sebelum kegiatan home visit dilakukan, guru akan membagi siswa ke dalam beberapa kelompok belajar atau cluster cluster belajar. Siswa yang rumahnya berdekatan akan dijadikan satu kelompok dan dikumpulkan di salah satu rumah siswa sesuai dengan kesepakatan dan kesediaan dari tuan rumah. Biasanya guru melakukan home visit ke dua hingga empat buah rumah siswa dalam sehari. Pembelajaran yang paling sering dilakukan pada saat kunjungan rumah atau home visit ini adalah membahas tentang mata pelajaran matematika hingga tuntas. Dalam pembelajaran melalui home visit guru tidak hanya bertemu dengan siswa tetapi dengan orang tua siswa ikut kegiatan belajar berkelompok, Kegiatan ini sangat baik karena membangun peran serta wali murid dalam kepedulian terhadap proses pembelajaran.

\section{Simpulan}

Berdasarkan hasil penelitian dan pembahasan dapat disimpulkan bahwa guru melakukan beberapa inovasi dalam pembelajaran di era pandemi diantaranya. Inovasi itu diwujudkan dalam membuat RPP berbasis blended learning dengan tahapan tahapan kegiatan pembelajarannya terdiri dari sintaks seeeking of information, acquisition of information dan synthesizing of knowledge. Kegiatan yang disusun dalam RPP dimulai dari proses pencarian informasi, kemudian diskusi serta evaluasi pembelajaran. Guru juga menggunakan berbagai teknik pembelajaran. Inovasi guru dalam proses pembelajaran di wujudkan melalui pembelajaran kombinasi antara pembelajaran tatap muka dan daring atau dikenal dengan blended learning.Siswa yang terkendala dengan pembelajaran secara daring, maka guru berinovasi melalui pembelajaran tatap muka seperti melalui kunjungan rumah atau home visit yang digunakan untuk berdiskusi dengan siswa dan orang tua siswa. Dengan harapan guru orang tua siswa dapat mendampingi proses belajar siswa selama di rumah. 


\section{Referensi}

Anugrahana, A. (2020). Hambatan, Solusi dan Harapan: Pembelajaran Daring Selama Masa Pandemi Covid19 Oleh Guru Sekolah Dasar. Scholaria: Jurnal Pendidikan dan Kebudayaan, 10(3), 282-289.

Anumpama Bhargava dan Mk Pathy, "Perseption of Student Teachers About Teaching Competencies" Vol 1 (1) (2011): 77.

Dewi, W. A. F. (2020). Dampak Covid-19 terhadap implementasi pembelajaran daring di Sekolah Dasar. Edukatif: Jurnal Ilmu Pendidikan, 2(1), 55-61.

Dokumen surat edaran nomor 4 tahun 2020. Tentang pelaksanaan kebijakan pendidikan dalam masa darurat penyebaran Corona virus Disease (Covid -19) dalam foramat PDf ditandatangani menetri pendidikan dan kebudayaan

Iriansyah, H. S. (2020, November). Membangun Kreatifitas Guru Dengan Inovasi Pembelajaran Di Masa Pandemi Covid-19. In Prosiding Seminar Nasional Pendidikan STKIP Kusuma Negara II (pp. 1-6).

Istiningsih, S., \& Hasbullah, H. (2015). Blended learning, Trend Strategi Pembelajaran Masa Depan. Jurnal Elemen, 1(1), 49-56.

Kurniawan, A. R. (2021). Home Visit Method Dalam Pembelajaran Luring Di Masa Pandemi Covid-19 Di Min 3 Musi Rawas (Doctoral dissertation, universitas jambi).

Makmun, S. (2021). Kombinasi Pembelajaran Media Daring Dengan Strategi Home Visit Pada Masa Pandemi Covid-19 Pada Sekolah Dasar Negeri 1 Batu Layar. Jurnal Ilmiah Telaah, 6(1), 20-25.

Nofitasari, E. (2021). Membangun Kreativitas Guru dengan Inovasi Pembelajaran di Masa Pandemi Covid19.

Novita sari,D,\&asbari,M. (2020). Peran kesiapan untuk berubah terhadap kinerja guru dimasa pandemi Covid19.jurnal of Industrial engineering \& manajemen research.I(2),219-237

Nugraha, D. M. D. P. (2020). Integrasi Pendidikan Karakter Dalam Penerapan Blended Learning Di Sekolah Dasar. Cetta: Jurnal Ilmu Pendidikan, 3(3), 472-484.

Panambaian, T. (2020). Penerapan Program Pengajaran dengan Model Blended Learning pada Sekolah Dasar di Kota Rantau. Journal Analytica Islamica, 9(1), 52-68.

Pujiasih, E. (2020). Membangun generasi emas dengan variasi pembelajaran online di masa pandemi covid19. Ideguru: Jurnal Karya Ilmiah Guru, 5(1), $42-48$.

Purwanto, A. (2020). Studi eksplorasi dampak Work from Home (WFH) terhadap kinerja guru selama pandemi COVID-19. EduPsyCouns: Journal of Education, Psychology and Counseling, 2(1), 92-100.

Sadikin, A., \& Hamidah, A. (2020). Pembelajaran Daring di Tengah Wabah Covid-19. Biodik, 6(2), 214-224.

Setyosari, P. 2015. Metode Penelitian Pendidikan dan Pengembangan. Malang : Prenamedia Group.

Sugiyono. 2017. Metode penelitian kuantitatif, kualitatif, dan R\&D. Bandung: Alfabeta

Susiyanti, E., \& Nugraheni, N. (2020, December). Penerapan Model Pembelajaran Daring Dengan Bantuan Video Pembelajaran Pada Masa Pandemi Covid-19. In Prosiding Seminar Nasional Institut Agama Hindu Negeri Tampung Penyang Palangka Raya (No. 1, pp. 77-92).

Syaharuddin, S. (2020). Pembelajaran Masa Pandemi: Dari Konvensional Ke Daring. Pembelajaran Masa Pandemi: Dari Konvensional Ke Daring.

Syarif, I. (2012). Pengaruh model blended learning terhadap motivasi dan prestasi belajar siswa SMK. Jurnal pendidikan vokasi, $2(2)$.

Widiara, I. K. (2018). Blended Learning Sebagai Alternatif Pembelajaran Di Era Digital. Purwadita: Jurnal Agama dan Budaya, 2(2), 50-56.

Yuliati, Y., \& Saputra, D. S. (2020). Membangun kemandirian belajar mahasiswa melalui Blended Learning di masa pandemi covid-19. Jurnal Elementaria Edukasia, 3(1). 